\title{
Elżbieta KOBOJEK*
}

\section{KRAJOBRAZ KULTUROWY DOLINY WARTY W OKOLICACH UNIEJOWA}

\begin{abstract}
Zarys treści: Krajobraz kulturowy jest historycznie ukształtowanym fragmentem przestrzeni geograficznej, powstałym w wyniku oddziaływań przyrodniczych i kulturowych. Odzwierciedla on współżycie ludzi z przyrodą. W artykule przedstawiono krajobraz kulturowy fragmentu doliny Warty w okolicach Uniejowa oraz dokonano próby jego oceny. Analizowano formy użytkowania terenu i stopień antropogenicznego przekształcenia krajobrazu na podstawie oceny udziału linii prostej w panoramie. Kilka wieków użytkowania ukształtowało w dolinie Warty w okolicach Uniejowa harmonijny wiejski krajobraz kulturowy. Struktura użytkowania ziemi wykazuje dostosowanie do przyrodniczych elementów środowiska doliny. Największą powierzchnię zajmują grunty orne (37,5\%) i lasy (36,2\%). Łąki, tak charakterystyczne dla den dolinnych, stanowią $21 \%$, a tereny zabudowane zaledwie $1,8 \%$ powierzchni. Najatrakcyjniejszy krajobraz dolinny został ukształtowany w obrębie terasy nadzalewowej niskiej. Występują tu największa mozaikowość użytkowania ziemi, długie miedze, liczne śródpolne zadrzewienia i szpalery drzew wzdłuż cieków wodnych. Przyrodniczo najcenniejsza jest terasa denna, pomimo dużego przekształcenia sieci rzecznej. W jej obrębie występują głównie łąki i lasy, zachowało się także najwięcej granic ekotonowych.
\end{abstract}

Slowa kluczowe: krajobraz kulturowy, tereny wiejskie, dolina Warty, Uniejów

\section{WPROWADZENIE}

Obecnie do elementów mających wpływ na jakość życia człowieka zaliczany jest także krajobraz. Przy czym jest to termin wieloznaczny i różnorodnie definiowany w zależności od dyscypliny naukowej ${ }^{1}$. Powszechnie rozumiany jest jako wygląd fragmentu powierzchni Ziemi dostrzegany z określonego miejsca. Zgodnie z Europejską Konwencją Krajobrazową krajobraz jest obszarem postrzeganym przez ludzi, którego charakter jest wynikiem działania i interakcji

${ }^{*}$ Elżbieta Kobojek, dr hab., prof. nadzw. UŁ, Katedra Zagospodarowania Środowiska i Polityki Przestrzennej Uniwersytetu Łódzkiego, 90-142 Łódź, ul. Kopcińskiego 31.

${ }^{1}$ D.L. Armand, Nauka o krajobrazie, PWN, Warszawa 1980; A. Richling, J. Solon, Ekologia krajobrazu, PWN, Warszawa 2002; M. Kistowski, Bierna ochrona krajobrazu jako podstawa utrzymania korzystnych warunków życia człowieka, „Przegląd Przyrodniczy” 2010, t. XXI, z. 2, s. 18-30; U. Myga-Piątek, Przemiany krajobrazów kulturowych w świetle idei zrównoważonego rozwoju, „Problemy Ekorozwoju” 2010, vol. 5, nr 1, s. 95-108. 
czynników przyrodniczych i/lub kulturowych ${ }^{2}$. Podobnie definiowany jest krajobraz kulturowy - jako historycznie ukształtowany fragment przestrzeni geograficznej, powstały w wyniku oddziaływań przyrodniczych i kulturowych ${ }^{3}$. Odzwierciedla on współżycie ludzi z przyrodą i przyczynia się do wykształcenia lokalnej tożsamości. Czytanie krajobrazu pozwala zrozumieć jego kształtowaną przez stulecia strukturę i dostrzec wartości przestrzeni oraz zachowane cechy lokalne. Analizując krajobraz, można lepiej poznać ludzi, którzy go stworzyli ${ }^{4}$. Zdaniem Bogdanowskiego ${ }^{5}$ współczesny krajobraz jest w pierwszym rzędzie odzwierciedleniem gospodarki człowieka. Dobra gospodarka stworzyła z reguły krajobrazy harmonijne, zła - dysharmonijne, a nawet dewastacyjne. I na odwrót - krajobraz dysharmonijny jest wyrazem złej gospodarki. Dlatego można powtórzyć za Ortegą y Gassetem: „Pokaż mi swój krajobraz, w którym żyjesz,

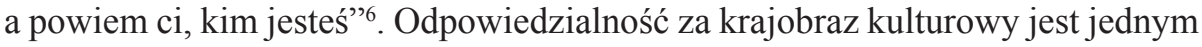
z warunków powodzenia zrównoważonego rozwoju.

Dolina rzeczna jest powszechną formą terenu w umiarkowanej strefie klimatycznej, w której woda jest bardzo ważnym czynnikiem środowiskotwórczym. Jest także pewnym typem środowiska przyrodniczego i złożonym układem ekologicznym ${ }^{7}$. Przez kolejne wieki dolinne środowisko było przez człowieka wykorzystywane i przekształcane. Rola, jaką przypisuje się rzekom w historii i gospodarce, w części przysługuje dolinom, które nie tracą swego znaczenia dla przyrody i dla człowieka - nawet wtedy, gdy rzeka zostanie uregulowana. Można mówić o dolinnym krajobrazie kulturowym, który odróżnia się od terenów z nim sąsiadujących.

Celem artykułu jest przedstawienie krajobrazu kulturowego fragmentu doliny Warty w okolicach Uniejowa i próba jego oceny. Dolina jest spójną formą geomorfologiczną i dlatego rozpatrywana jest w granicach przyrodniczych, a nie administracyjnych. W przypadku doliny rzecznej sposób użytkowania i zagospodarowania zależy od sytuacji topograficznej i budowy geologicznej, dlatego analizowano krajobraz w odniesieniu do elementów dolinnych. Starano się także wskazać skalę antropogenicznego przekształcenia krajobrazu. Rozwojowi miasta uzdrowiskowego, jakim jest teraz Uniejów, sprzyjać może harmonijny i zadbany krajobraz.

${ }^{2}$ Europejska Konwekcja Krajobrazowa sporządzona we Florencji dnia 20 października 2000 r., Dz.U. Nr 14, poz. 98 z dnia 29 stycznia 2006 r.

${ }^{3}$ U. Myga-Piątek, Przemiany krajobrazów kulturowych...; Ustawa z dnia 23 lipca 2003 r. o ochronie zabytków i opiece nad zabytkami (Dz.U. Nr 162, poz. 1568 z późn. zm.)

${ }^{4}$ K. Kopczyński, Edukacyjne walory krajobrazu kulturowego, „Problemy Ekologii Krajobrazu" 2009, t. XXV, s. 53-62.

${ }^{5}$ J. Bogdanowski, Problemy architektury krajobrazu rzecznego, [w:] J. Kułtuniak (red.), Rzeki. Kultura - cywilizacja - historia, t. 2, Wydawnictwo Śląsk, Katowice 1993, s. 61-75.

${ }^{6}$ Tamże, s. 62.

${ }^{7}$ R. Olaczek, Antropogeniczne czynniki przekształcenia dolin rzecznych, [w:] J. Kułtuniak (red.), Rzeki. Kultura - cywilizacja - historia, t. 9, Wydawnictwo Śląsk, Katowice 2000, s. 119-142; E. Kobojek, Naturalne uwarunkowania równych reakcji rzek nizinnych na antropopresję na przykładzie środkowej Bzury i jej dopływów, Wydawnictwo Uniwersytetu Łódzkiego, Łódź 2009. 


\section{METODY BADAŃ I OCENY KRAJOBRAZU}

Krajobraz kulturowy jest najczęściej uzależniony od sposobu zagospodarowania. W przypadku dolin zasadniczym tłem gospodarki nadal jest środowisko przyrodnicze. Można wskazać w dolinie rzecznej jednostki krajobrazowe stanowiące tereny jednolite pod względem ukształtowania, budowy geologicznej i użytkowania.

Do analizy wybrano fragment doliny Warty w okolicach Uniejowa o długości 2,5 km. Południową granicę terenu wyznacza droga numer 72, a północną linia łącząca wsie Ostrowsko, Wieścice i Dąbrowa (ryc. 1). Dolina rzeczna ma w tym odcinku szerokość od 8 do $6 \mathrm{~km}$, a samo jej dno osiąga wartość 2,5 km. Zasięg i elementy doliny wyznaczono na podstawie analizy mapy topograficznej w skali 1:10 000 i 1:5 000 oraz Szczegółowej Mapy Geologicznej Polski w skali 1:50 000 arkusz Uniejów i arkusz Dobra ${ }^{8}$. Następnie analizowano formy użytkowania terenu i stopień antropogenicznego przekształcenia krajobrazu. Użytkowanie ziemi w dolinie określono na podstawie wyliczeń udziału powierzchni zajętych przez podstawowe formy użytkowania: grunty orne, użytki zielone, wody stojące, obszary leśne i zabudowane. Podstawą wyliczeń były dane z Corin Land Cover i ortofotomapa dostępna na witrynie Geportal.gov.pl. Użytkowanie gruntów zostało skorygowane w terenie w marcu i kwietniu 2016 r.

W celu określenia stopnia antropogenicznego przekształcenia krajobrazu posłużono się metodą oceny udziału linii prostej w widoku i panoramie. W naturalnych systemach przyrodniczych, pozbawionych śladów działalności człowieka, prawie nie ma linii prostych. Rzeki i płaty naturalnej roślinności mają brzegi nieregularne. To człowiek wprowadził do krajobrazu linie proste: geometryczny podział pól, linie dróg, krawędzie obiektów budowlanych. Oceniając udział linii prostej w stosunku do innych linii obserwowanych w widoku, można określić stopień antropogenicznego przekształcenia tego fragmentu krajobrazu' ${ }^{9}$. Widok jest fragmentem fizjonomii krajobrazu, odbieranym przez obserwatora z określonego miejsca, w jednym polu widzenia. Miarą zasięgu widoku jest zakres widzialności przy spojrzeniu w określonym kierunku, odpowiadający kątowi około $60^{\circ 10}$. Aby ocenić stopień antropogenicznego przekształcenia krajobrazu, dokonano rejestracji fotograficznej analizowanego widoku. Na podstawie fotografii wykonano rysunek uproszczony, zaznaczając różne typy linii: linie proste twarde (np. obrysy budynków), linie proste miękkie (proste miedze w terenie równinnym), linie faliste (np. brzegi rzeki, miedze na stokach), linie labiryntowe (obrys płatów leśnych) lub pasma ekotonowe (lustro wody rzeki - roślinność pływająca

${ }^{8}$ J. Kamiński, J. Forysiak, Szczegółowa Mapa Geologiczna Polski w skali 1:50 000, arkusz Uniejów (588), PIG, Warszawa 2008; J. Czyż, J. Forysiak, J. Kamiński, H. Klatkowa, Szczegółowa Mapa Geologiczna Polski w skali 1:50 000, arkusz Dobra (587), PIG, Warszawa 2004.

${ }^{9}$ T.J. Chmielewski, Systemy krajobrazowe. Struktura - Funkcjonowanie - Planowanie, PWN, Warszawa 2012, s. 65-74.

${ }^{10}$ K. Wejchert, Elementy kompozycji urbanistycznej, Wydawnictwo Arkady, Warszawa 1984, s. $1-279$. 
- szuwar lub ściana lasu - krzewy - ziołorośla). Szczególną uwagę zwrócono właśnie na granice ekotonowe, czyli naturalne strefy styku dwóch sąsiadujących ze sobą ekosystemów ${ }^{11}$. Mają one charakter łagodnego, szerokiego, gradientowego przejścia z jednego ekosystemu do drugiego (np. torfowisko-las), bądź też mogą być wąskie, skokowe (koryto rzeczne-las na skarpie nadrzecznej). Działalność człowieka wpływa na zmniejszenie udziału szerokich ekotonów w krajobrazie na rzecz dominacji granic ostrych, prostoliniowych. Następnie obliczono długość wszystkich rodzajów linii w obrębie poszczególnych podstawowych form powierzchni, a wyniki przedstawiono $\mathrm{w}$ procentach. Przeanalizowano $\mathrm{w}$ ten sposób krajobraz zarejestrowany na 120 fotografiach.

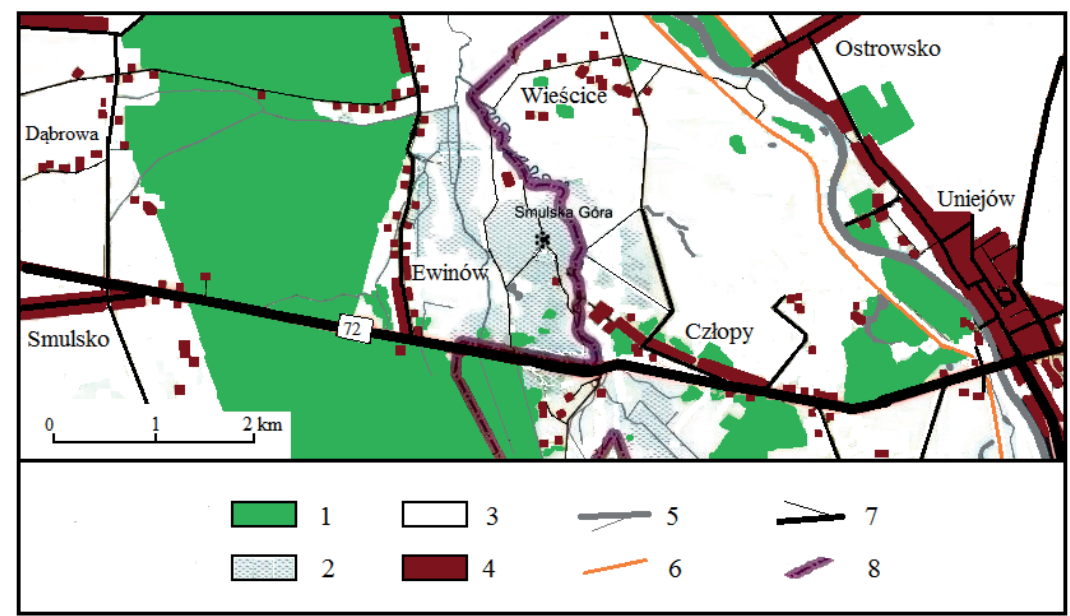

Ryc. 1. Zasięg przestrzenny terenu badań w dolinie Warty

1 - lasy, 2 - torfowisko zajęte przez łąki, 3 - pola i łąki, 4 - zabudowania, 5 - rzeki i cieki, 6 - wały przeciwpowodziowe, 7 - drogi, 8 - granica województw Źródło: opracowanie własne

\section{FORMY UŻYTKOWANIA ZIEMI NA TLE ŚRODOWISKA PRZYRODNICZEGO DOLINY RZECZNEJ}

W obrębie szerokiej doliny Warty występują cztery poziomy dolinne: najwyższy poziom erozyjny (warciański), dwa poziomy teras nadzalewowych (wyższa ukształtowana $\mathrm{w}$ plenivistulianie i niższa $\mathrm{z}$ późnego vistulianu) oraz poziom najniższy - terasa denna (dawna równina zalewowa kształtowana w holocenie). Powierzchnie te różnią się nie tylko wysokościami względnymi, ale przede wszystkim budową litologiczną, glebami i głębokością zalegania poziomu wód gruntowych, co ma ogromny wpływ na charakter siedlisk. Strefy siedliskowe i związane z nimi ekosystemy dolinne są uporządkowane strefowo w przekroju

${ }^{11}$ T.J. Chmielewski, Systemy krajobrazowe... 


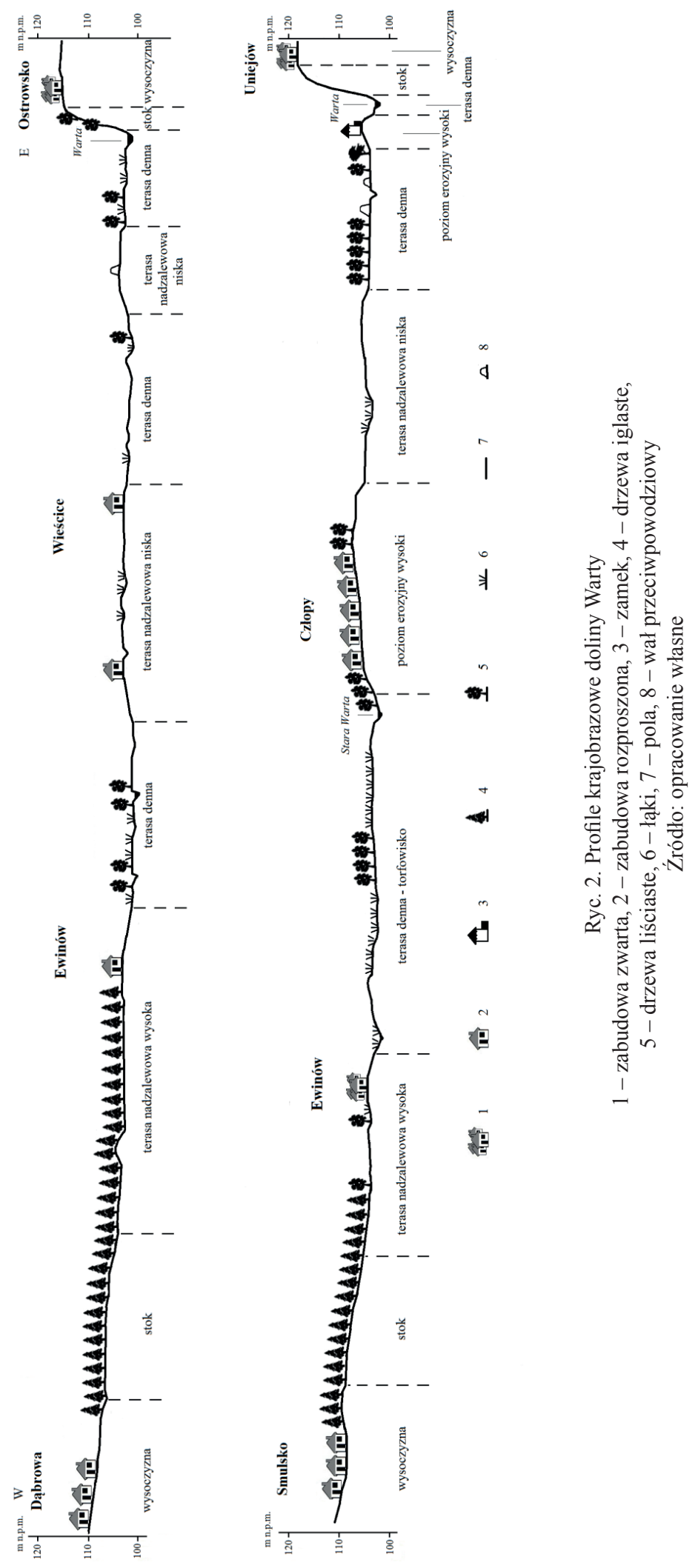


poprzecznym doliny, a także wzdłuż biegu rzeki. Nie jest to jednak porządek geometryczny, a mozaikowy. Stoki doliny są asymetryczne. Stok wschodni jest wyższy i stromy, a zachodni niższy i łagodniejszy (ryc. 2).

Ogólnie w analizowanym odcinku doliny dominują grunty orne zajmujące $37,5 \%$ oraz lasy, które stanowią 36,2\% powierzchni (ryc. 3). Znaczny udział, $24,1 \%$ powierzchni, mają także łąki. Tereny zabudowane zajmują $1,8 \%$, a wody stojące zaledwie $0,4 \%$ powierzchni doliny.

Wyraźnie zarysowują się w dolinie cztery strefy ze względu na użytkowanie ziemi. Przesuwając się od wschodniej ku zachodniej części doliny, wskazać można następujące dominujące formy użytkowania: 1) wzdłuż rzeki Warty występuje wąski pas łąk ze znacznym udziałem lasów liściastych lub krzewów, 2) szeroki pas gruntów ornych poprzedzielanych pasmami łąk i urozmaicony małymi zbiornikami wód stojących, 3) szeroki pas łąk, 4) zwarta powierzchnia lasów iglastych (ryc. 2).

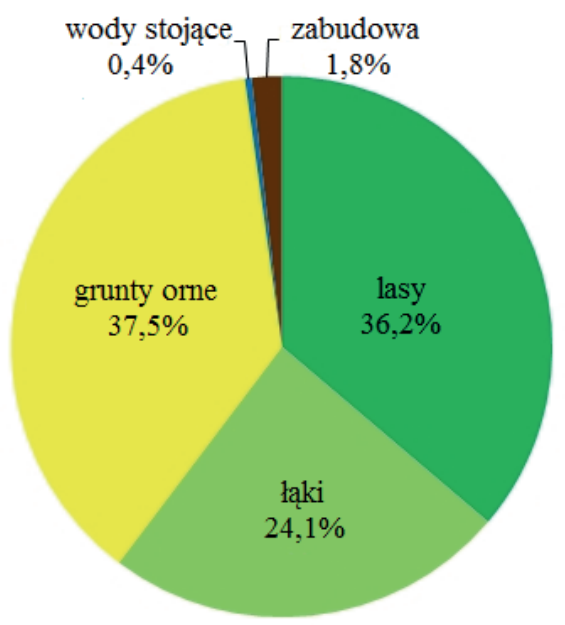

Ryc. 3. Struktura użytkowania ziemi w analizowanym odcinku doliny Warty Źródło: opracowanie własne

Formy użytkowania ziemi mające wpływ na krajobraz ściśle nawiązują do środowiska przyrodniczego elementów doliny rzecznej, chociaż przeprowadzono liczne prace regulacyjne i melioracyjne. Najniżej (100-102 m n.p.m.) położona jest terasa denna, czyli powierzchnia ukształtowana przez procesy fluwialne (korytowe i powodziowe) w holocenie, a obecnie zajęta głównie przez łąki. Jest to dawna terasa zalewowa Warty z licznymi starorzeczami. Do XIX wieku Warta była rzeką wielokorytową, tzn. woda odpływała kilkoma równoległymi korytami, łączącymi się ze sobą i swobodnie rozdzielającymi, między którymi były stabilne wyspy ${ }^{12}$. W czasie wiosennych, rzadziej letnich, wezbrań znaczna

${ }^{12}$ J. Forysiak, Rozwój doliny Warty między Burzeninem i Dobrowem po zlodowaceniu warty, „Acta Geogr. Lodz.” 2005, Vol. 90. 
część terasy była zalewana wodami, które pozostawały 2-3 tygodnie. Dlatego powierzchnia ta zbudowana jest z piasków z wkładkami mułów organicznych, miejscami przykrytych madami. Przy wysokich stanach wody wyspy nie były podtapiane. W ciągu kilku wieków system wielokorytowy był sukcesywnie ograniczany poprzez zasypywanie elementarnych koryt, prostowanie i faszynowanie. Największy wpływ na ten proces mieli osadnicy olęderscy, sprowadzeni do basenu uniejowskiego w XVIII w. ${ }^{13}$ Ostateczne ograniczenie systemu do jednego koryta nastąpiło w latach trzydziestych XX w., gdy uregulowano rzekę i zakończono budowę wałów przeciwpowodziowych, zamykając między nimi współczesne koryto Warty ${ }^{14}$.

Usypane w XIX i XX w. wały przeciwpowodziowe odcięły od zalewów znaczną część dna doliny Warty (ryc. 4). Skutkiem tych prac jest podział dawnej równiny zalewowej na dwie części: mniejszy powierzchniowo obszar położony między współczesnym korytem Warty a wałem przeciwpowodziowym i rozleglejszy poza wałami. Tereny położone w bezpośrednim sąsiedztwie Warty są zalewane w czasie wezbrań i wilgotniejsze. Zajmują je głównie łąki, zarośla i małe powierzchniowo lasy liściaste, głównie łęgi nadrzeczne (np. topolowe). W obrębie tej powierzchni częściowo położony jest także park zamkowy w Uniejowie ${ }^{15}$.

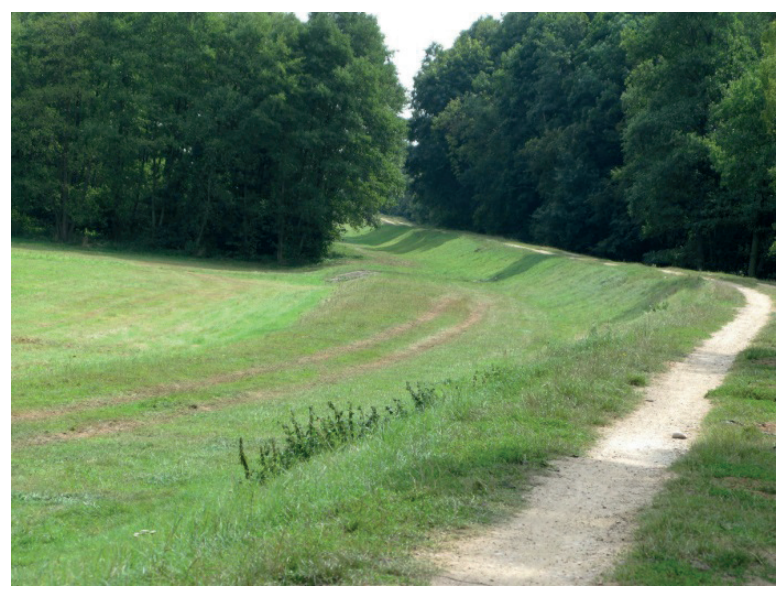

Ryc. 4. Ścieżka na wale przeciwpowodziowym we wschodniej części doliny Warty (fot. E. Kobojek, 2015)

${ }^{13}$ J. Forysiak, M. Kulesza, J. Twardy, Wptyw osadnictwa olęderskiego na sieć rzeczna i morfologię międzyrzecza Warty i Neru, [w:] E. Smolska, P. Szwarczewski (red.), Zapis działalności człowieka w środowisku przyrodniczym, t. III, Wydawnictwo Szkoły Wyższej Przymierza Rodzin, Warszawa 2007, s. 39-45.

${ }^{14}$ J. Petera-Zganiacz, J. Forysiak, Historia rozwoju doliny Warty $w$ basenie uniejowskim, „Biuletyn Uniejowski: 2012, nr 1, s. 23-41; E. Kobojek, Wptyw warunków klimatycznych na system fluwialny i melioracje wodne w pradolinach w rejonie Łowicza i Koźmina (Polska Środkowa), „Przegląd Naukowy. Inżynieria i Kształtowanie Środowiska” 2015, vol. 24(4), nr 70, s. 381-390.

${ }^{15} \mathrm{M}$. Borowska-Stefańska, Zagospodarowanie terenów zagrożonych powodziami $w$ Uniejowie, „Biuletyn Uniejowski” 2015, nr 4, s. 131-142. 
Druga część terasy dennej, pozostająca na zewnątrz wałów przeciwpowodziowych, tylko sporadycznie jest zalewana i to z powodu podniesienia wód gruntowych, czyli podtopienia. W jej obrębie zachowały się jeszcze starorzecza (ryc. 5). Zbiorniki wodne mają charakterystyczny wydłużony kształt, a ich bogactwo florystyczne jest nieco mniejsze niż w międzywalu ${ }^{16}$. Powierzchnia tej części terasy dennej jest także zajęta głównie przez łąki, czasem przedzielone pasmem gruntów ornych. Brzegi starorzeczy porastają drzewa i krzewy.

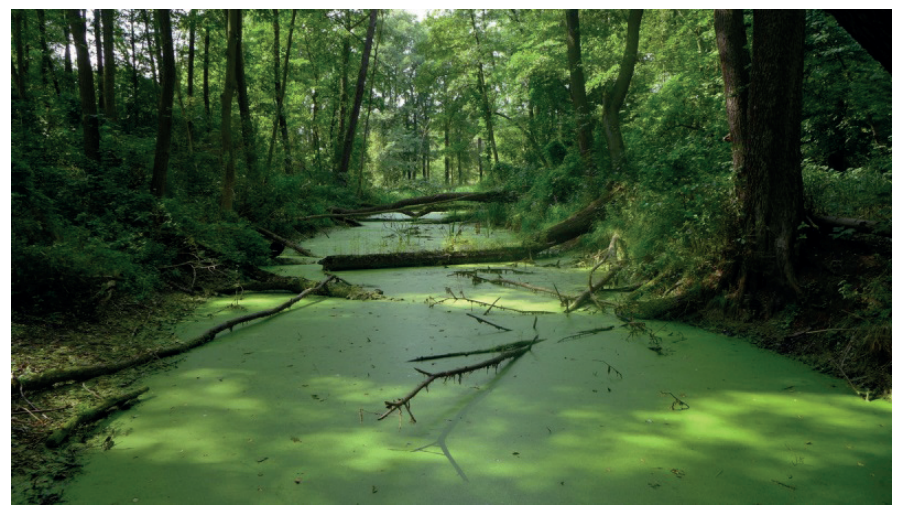

Ryc. 5. Starorzecze we wschodniej części doliny Warty

(fot. E. Kobojek, 2015)

W zachodniej części dna doliny, między wsiami Człopy i Ewinów, występuje zmeliorowane niskie torfowisko przecięte małym ciekiem o zadrzewionych brzegach (ryc. 6). Także tutaj zachowały się odcięte koryta. Pomimo niewielkiej miąższości torfu teren jest wilgotny i użytkowany jako kośna łąka. W najwilgotniejszych fragmentach pozostały lasy. Wśród tej podmokłej powierzchni, na niewielkim wzniesieniu ulokowane jest grodzisko Smulska Góra. W obrębie terasy dennej występują prawie wszystkie zinwentaryzowane zbiorniki wodne, głównie starorzecza i fragmenty odciętych koryt.

Terasa nadzalewowa niższa dominuje we wschodniej i środkowej części doliny, a jej powierzchnia wznosi się na wysokości 104-103 m n.p.m. Terasa ta jest bardzo ważnym elementem doliny Warty w analizowanym odcinku. Cechuje się znaczną szerokością, 2-2,5 km, ale porozcinana jest przez wąskie obniżenia dawnych koryt, np. na południe od Wieścic. Zbudowana jest głównie z piasków średnioziarnistych z domieszką mułków, miejscami przykrytych przez piaski eoliczne, np. w Wieścicach zachowała się niewielka wydma. Są to obszary suchsze, leżące poza corocznym zasięgiem wód powodziowych. Gleby są zwykle ubogie i kwaśne. W obrębie tej terasy dominują grunty orne, tylko miejscami rozdzielone łąkami i obniżeniami z paleokorytami. Piaski wydmowe porasta las iglasty. Zabudowa jest rozproszona, przy czym dominują pojedyncze zagrody (ryc. 7).

${ }^{16}$ L. Kucharski, A. Barcka, B. Chmielecki, Flora starorzeczy $w$ dolinie Warty - stan, zagrożenia oraz możliwości ochronnych, „Biuletyn Uniejowski” 2013, nr 2, s. 23-38. 
Jest to ważny krajobrazowo obszar, najbardziej urozmaicony, ponieważ występuje tu mozaika gruntów ornych, pasm łąk, wody stojącej, zadrzewień i rozproszonej zabudowy.

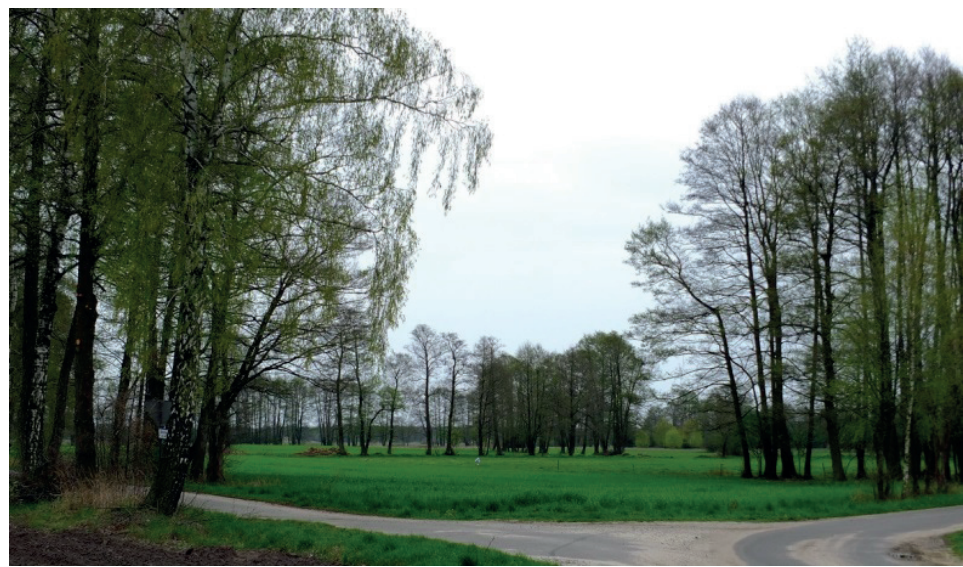

Ryc. 6. Szpalery drzew w obrębie zmeliorowanego torfowiska

(fot. E. Kobojek, 2016)

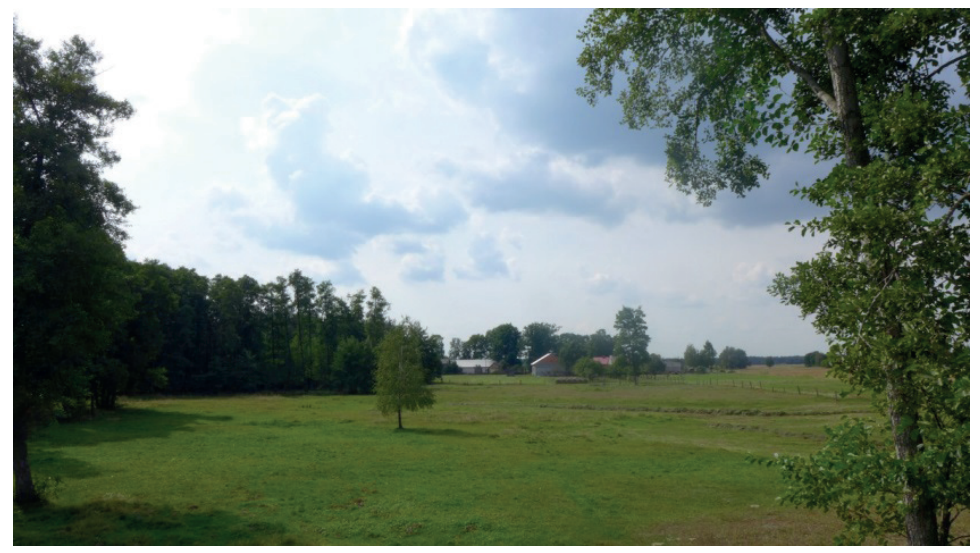

Ryc. 7. Fragment terasy nadzalewowej niskiej we wschodniej części doliny Warty (fot. E. Kobojek, 2015)

Terasa nadzalewowa wysoka ciągnie się w postaci spłaszczenia w zachodniej części doliny. W Ewinowie ma ona $2 \mathrm{~km}$ szerokości i położona jest na wysokości 106-108 m n.p.m., czyli 4,5-5,5 m powyżej dna doliny. Zbudowana jest głównie z piasków średnioziarnistych, a w stropie występują drobnoziarniste piaski eoliczne ${ }^{17}$. Cechy osadów podłoża spowodowały, że jest to sucha powierzchnia zajęta przez największy kompleks leśny w tym fragmencie doliny - las iglasty. Jedynie we wschodniej części poziomu występuje zabudowa wsi Ewinów.

${ }^{17}$ J. Forysiak, Rozwój doliny Warty... 
Układ przestrzenny nawiązuje do krawędzi terasy, wzdłuż której prowadzi droga będąca osią komunikacyjną wsi. Zabudowa jest w przewadze zwarta.

W południowej części analizowanego obszaru zachował się także ostaniec poziomu erozyjnego (warciańskiego). Jest to najwyższy poziom sięgający $109 \mathrm{~m}$ n.p.m. Zbudowany jest w spągu z gliny zwałowej, a w stropie z osadów piaszczystych. W obrębie tej powierzchni zlokalizowana jest częściowo zabudowa wsi Człopy. Także zamek w Uniejowie został ulokowany w obrębie małego fragmentu tej powierzchni.

Wschodnie zbocze doliny, wysokie (do $10 \mathrm{~m}$ ), strome, zbudowane z gliny zwałowej, jest przeważnie zadrzewione, jedynie w obrębie Uniejowa zabudowane. Zbocze zachodnie jest łagodniejsze, zbudowane z piasków fluwioglacjalnych i porośnięte lasem iglastym.

Wody powierzchniowe i gruntowe, pomimo ogromnych przekształceń antropogenicznych, są nadal najważniejszymi czynnikami mającymi wpływ na zróżnicowanie roślinności i sposoby użytkowania terenu. Naturalnych form pokrycia terenu (m.in. torfowiska, starorzecza) jest jednak niewiele. Rozległe torfowisko w zachodniej części dna doliny jest zmeliorowane i częściowo osuszone. Dość dużo zachowało się jednak form półnaturalnych. Zaliczane są do nich układy przyrodnicze, w skład których wchodzą gatunki naturalnie występujące w środowisku, a utrzymywane przez gospodarczą działalność człowieka, np. wielogatunkowe łąki, lasy gospodarcze. Za antropogeniczne formy pokrycia terenu uznane zostały: łąki zmeliorowane, pola, parki, tereny zabudowy, tereny komunikacyjne. Jednak pomimo wielowiekowego wykorzystania doliny Warty użytkowanie gruntów jest dostosowane do środowiska przyrodniczego.

\section{SKALA PRZEKSZTAŁCENIA KRAJOBRAZU NA PODSTAWIE UDZIAŁU LINII PROSTEJ W WIDOKU}

Przewodnim rysem krajobrazu doliny Warty jest równinność i rolnicze użytkowanie gruntu. Stan zachowania środowiska naturalnego i antropogeniczne przekształcenie krajobrazu są zmienne w zależności od elementu doliny. Także udział linii prostej w widoku i panoramie wskazuje na pewne różnice w obrębie poszczególnych elementów doliny.

Największy udział linii prostej twardej w widoku świadczący o dużym przekształceniu krajobrazu występuje w obrębie fragmentu zbocza Warty w Uniejowie - wynosi on aż $47 \%$ (ryc. 8). Podczas gdy w obrębie całego wschodniego zbocza osiąga tylko $12 \%$. W Uniejowie zbocze jest w niektórych miejscach łagodzone, terasowane i zajmowane przez nową zabudowę, głównie hotelową.

W dolinie Warty zauważalna jest wyraźna tendencja - im niżej położona powierzchnia dolinna, tym mniejszy jest udział zabudowy i tym samym mniejszy udział linii prostej twardej. Największą skalę przekształcenia krajobrazu wykazują dwa ostańce erozyjne, których powierzchnie położone są oczywiście najwyżej w obrębie rozległego dna doliny Warty (ryc. 2). Udział linii prostej twardej 


\section{terasa denna}

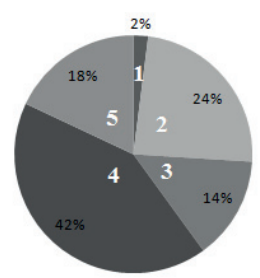

lagodny stok lączący terasę nadzalewową niską $i$ denną

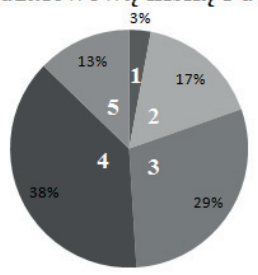

terasa nadzalewowa wysoka

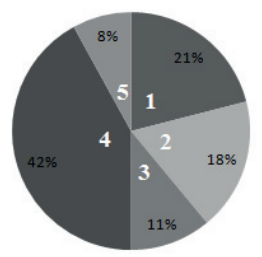

wschodnie zbocze doliny

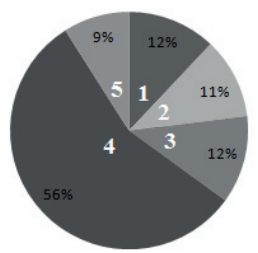

torfowisko

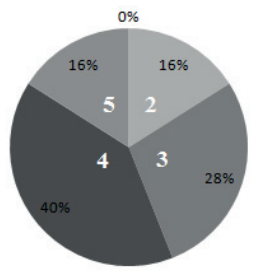

terasa nadzalewowa niska

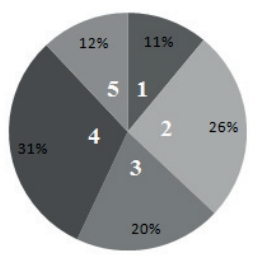

poziom erozyjny

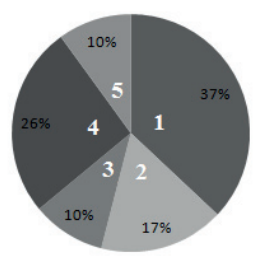

zbocze doliny w Uniejowie

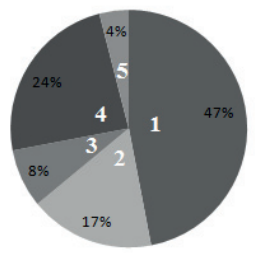

Typy linii w krajobrazie

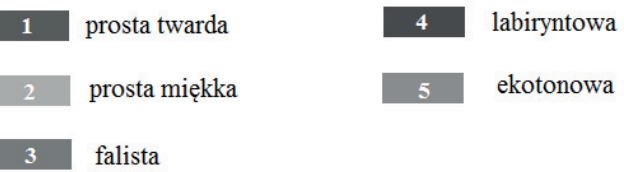

Ryc. 8. Procentowy udział różnych typów linii w krajobrazie poziomów dolinnych Warty Źródło: opracowanie własne 
wynosi $37 \%$. Wartość ta związana jest z zabudową wsi Człopy, zamkiem w Uniejowie i obiektami geotermalnymi. Znaczny udział, 21\% linii twardej, wyliczony został dla terasy nadzalewowej wysokiej. W obrębie tej powierzchni położony jest fragment wsi Człopy i Ewinów w zachodniej części doliny. W obrębie poziomów erozyjnego i terasy nadzalewowej z powodu dobrych warunków dla osadnictwa dominuje zabudowa wiejska zwarta. Z kolei w obrębie terasy nadzalewowej niskiej i na rozległym stoku łączącym tę powierzchnię z terasą denną zabudowa jest rozproszona - często występują grupy tylko dwóch lub trzech gospodarstw. Udział linii prostej twardej dla terasy niskiej wynosi $11 \%$, a dla stoku ku terasie dennej zaledwie 3\%. Zabudowa rozproszona związana jest $\mathrm{z}$ warunkami topograficznymi - w obrębie wyżej wzniesionych wysp otoczonych powierzchnią zalewową. Pojedyncze zabudowania, głównie domy letniskowe, spotkać można na terasie najniższej dennej, dlatego udział linii twardej wyliczono na $1 \%$. Tylko w obrębie obszaru osuszonego torfowiska między wsiami Człopy i Ewinów nie ma zabudowy i nie odnotowano linii twardych.

Udział linii prostych miękkich związany jest z obecnością wyraźnych miedz pomiędzy polami lub polem i łąką, ale w obrębie płaskiej powierzchni dolinnej. Największy udział tych linii wyliczono dla terasy nadzalewowej niskiej (26\%) i terasy dennej (24\%). Te dwie powierzchnie są najintensywniej użytkowane rolniczo. W wielu dolinach także terasa nadzalewowa wysoka jest użytkowana rolniczo, ale w przypadku analizowanego odcinka doliny Warty udział pól jest mniejszy (co wyraża się 18\% wartością linii prostej miękkiej) z powodu słabych gleb na piaszczystym podłożu.

Zmienny jest udział linii falistej w krajobrazie, ponieważ waha się od 8 do $29 \%$. Największą wartość wyliczono dla rozległego stoku łączącego powierzchnię terasy nadzalewowej niskiej $\mathrm{z}$ terasą denną. Jest to spowodowane różnicą wysokości między tymi powierzchniami rzędu 1,5-2 m oraz granicami pól ułożonymi prostopadle do poziomic. Ponadto powierzchnia terasy niskiej w wielu miejscach jest porozcinana obniżeniami dawnych koryt o szerokości 50-150 m. Wszystko to powoduje, że powierzchnia jest falista i dodatkowo podkreślona przez wyraźne miedze. Przeplatają się tutaj łąki, grunty orne, śródpolne zadrzewienia i zagłębienia starorzeczy.

O udziale linii labiryntowych w krajobrazie decyduje obecność granic lasów i zwartych grup drzew. Duży udział linii tego rodzaju występuje na wschodnim zboczu doliny Warty, ponieważ zachowały się fragmenty małych powierzchniowo lasów, zarośla i liczne grupy drzew. Także w obrębie innych powierzchni dolinnych (poza poziomem erozyjnym) udział linii labiryntowych jest znaczny i waha się od 31 do $42 \%$. Jednak duży udział linii labiryntowych dla terasy nadzalewowej wysokiej (42\%) i terasy dennej (42\%) powinien być nieco inaczej interpretowany. W przypadku terasy wysokiej o wartości tej zdecydowała obecność rozległego kompleksu leśnego. Atrakcyjna krajobrazowo jest w zasadzie tylko granica tego lasu. Zupełnie inaczej sytuacja wygląda dla terasy dennej. O dużym udziale linii labiryntowej zdecydowały obecność małych powierzchniowo lasów oraz bardzo licznie występujące śródpolne zadrzewienia. W obrębie tej 
powierzchni występują także starorzecza oraz cieki, których brzegi porastają grupy drzew lub krzewów (olsza i wierzba). Taki krajobraz jest mozaikowy i zdecydowanie atrakcyjniejszy.

Najcenniejsze z punktu widzenia wartości środowiska przyrodniczego są linie ekotonowe, czyli strefy kontaktu o szerokości 10-20 m. Szczególnie szerokie są w przypadku brzegów starorzeczy i torfowisk. Największy procentowy udział tego typu granicy w krajobrazie występuje w obrębie powierzchni najniżej położonych w dolinie. Dominuje pod tym względem terasa denna z 18\% udziałem linii ekotonowych. Granice ekotonowe występują miejscami wzdłuż brzegu Warty (wikliny nadrzeczne, lokalnie łęgi, łąki), a przede wszystkim na brzegach starorzeczy. Obszar przykorytowy ma charakter mieszany leśno-zaroślowy z udziałem muraw i łąk. Nieznacznie mniejszy udział granic ekotonowych wyliczono dla powierzchni torfowiskowej (16\%). Na terasie nadzalewowej niskiej i jej stoku ku terasie dennej linie ekotonowe stanowią $12-13 \%$. Na terasie nadzalewowej wysokiej ich udział wynosi tylko $8 \%$. Granice ekotonowe zaobserwowano głównie między korytem małego cieku i lasem. Bardzo mały udział linii ekotonowych wyliczono dla zbocza doliny Warty w Uniejowie. Jest to dosyć zrozumiałe, ponieważ do cech przestrzeni miejskiej należą bezpieczeństwo i pielęgnowana zieleń.

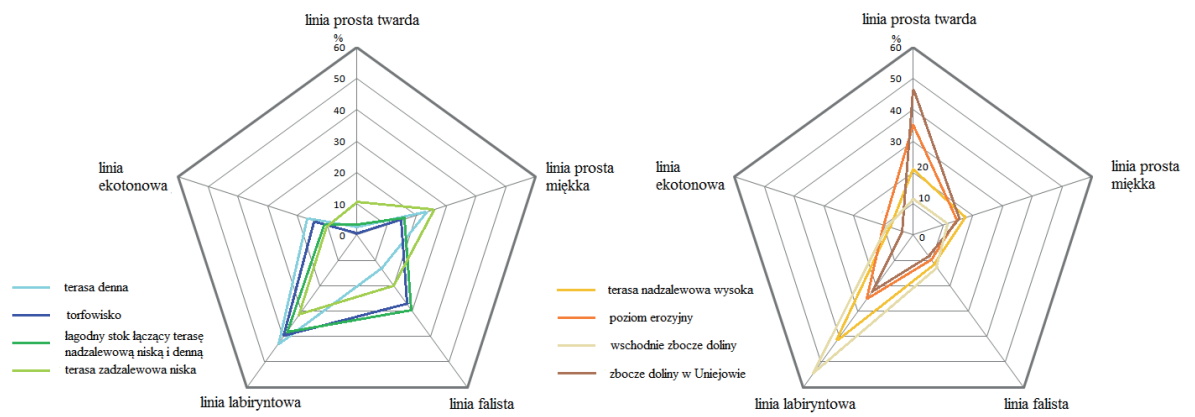

Ryc. 9. Skala przekształcenia krajobrazu w dolinie Warty w okolicach Uniejowa Źródło: opracowanie własne

Na podstawie udziału różnych typów linii w widoku można stwierdzić, że najmniej elementów bezpośrednio ingerujących w krajobraz jest w obrębie terasy dennej, torfowiska i terasy nadzalewowej niskiej (ryc. 9). Nie oznacza to jednak, że te elementy środowiska pozostają w stanie naturalnym. W XIX wieku silnie został przekształcony system rzeczny w dnie doliny Warty, rzekę uregulowano, a torfowisko zmeliorowano i silnie osuszono. Znaczna część powierzchni jest zajęta przez łąki lub pola. Pomimo takich prac nadal terasa denna wyróżnia się największym udziałem linii labiryntowych i ekotonowych. Krajobraz torfowiska zmeliorowanego wyróżnia się brakiem linii prostych twardych i największym udziałem linii falistej. 
Zdecydowanie większe przekształcenia zostały wprowadzone w obrębie poziomów wyższych, tzn. na terasie nadzalewowej wysokiej, poziomie erozyjnym i zboczu doliny. Występuje tutaj duży udział linii prostej twardej, czyli zabudowy, ale także linii labiryntowej (zadrzewienia). Jednak zastosowana metoda udziału linii w krajobrazie nie ocenia wartości historycznych i kulturowych zabudowy, a w przypadku Uniejowa są one duże.

Należy podkreślić, że głównym elementem krajobrazu doliny Warty są użytki rolne oraz układy gruntów, czyli rozłogi wsi, co często jest podkreślane w literaturze poświęconej tym zagadnieniom ${ }^{18}$. Obręby ewidencyjne utworzono w ramach katastru ziemi w XIX w. i od tamtego czasu rozłogi istnieją w mało zmienionej postaci. Zwykle im bardziej zróżnicowane środowisko, tym bardziej złożone są układy gruntów. W dolinie Warty zdecydowanie przeważają rozłogi pasmowe, a ich granice są dopasowane do granic naturalnych, dlatego krajobraz jest harmonijny.

Najcenniejszym uzupełnieniem rozłogu i krajobrazu rolniczego są zadrzewienia śródpolne ${ }^{19}$. W obszarze torfowym są to drzewa liściaste i gęste krzewy - obszar zieleni jest zwarty i miejscami trudno dostępny. W obrębie terasy dennej zwykle kilka lub kilkanaście drzew rośnie w zagłębieniu. Wyjątkowy urok mają szpalery drzew wzdłuż cieków wodnych rozcinających powierzchnię równiny.

Odbiór krajobrazu rolniczego zależy od kształtu i wielkości działek, liczby miedz i zadrzewień śródpolnych ${ }^{20}$. Jeżeli na widnokręgu jest rozległe pole zaorane w jednym kierunku, bez drzew, to krajobraz jest monotonny. Z kolei więcej rozdrobnionych działek rolniczych (zróżnicowanie) podnosi walory krajobrazowe. Działki długie pasmowe sprawiają wrażenie symetrii i ruchu, a mniejsze blokowo-pasmowe żywiołowości i niestabilności. Także rozległe powierzchnie zajęte tylko przez łąki (brak miedz) i duże blokowe działki tworzą krajobraz monotonny. Wszędzie tam gdzie jest zmienność, np. pole-łąka-drzewo śródpolne, to są także mozaikowość, żywiołowość i ruch. Taki układ występujący w dnie doliny Warty tworzony był przez setki lat, a zależny jest od zjawisk przyrodniczych oraz intensywności gospodarowania. Ten szachownicowy układ gruntów nadaje kolorytu i ożywia krajobraz nie tylko dolinny, ale także nizinny ${ }^{21}$.

Nieco inaczej należy ocenić znaczenie lasu w krajobrazie. Lasy mają charakter wielofunkcyjny ${ }^{22}$. Są bardzo ważne jako obiekty turystyki i rekreacji, edukacji ekologicznej, dydaktyki, a także ochrony przyrody i środowiska przyrodniczego - spełniają funkcje społeczne. $\mathrm{Z}$ kolei funkcja krajobrazowa oznacza ich

${ }^{18}$ L. Kozłowski, Rozłogi wsi jako treść krajobrazu, Studia Obszarów Wiejskich, t. XXIX, 2012, s. 9-30.

${ }^{19}$ M. Nowak-Rząsa, Transformacja krajobrazów Polski - ocena kierunków i perspektywy rozwoju, [w:] D. Chylińska, J. Łach (red.) Studia krajobrazowe a ginace krajobrazy, Uniwersytet Wrocławski, Wrocław 2010, s. 21-28.

${ }^{20}$ L. Kozłowski, Rozłogi wsi...

${ }^{21}$ J. Tkocz, Organizacja przestrzenna wsi w Polsce, Wydawnictwo Uniwersytetu Śląskiego, Katowice 1998.

${ }^{22}$ J.K. Kurowski, Ekologia i ochrona roślinności lessnej, EKO-GRAF Adam Świć, Łódź 2015. 
konserwującą rolę w odniesieniu do naturalnego, urozmaiconego ukształtowania terenu. Krajobraz leśny prezentuje wyróżniające się walory estetyczne. Szczególnie cenne krajobrazowo są granice lasu i śródleśne polany.

\section{WNIOSKI}

Doliny rzeczne w umiarkowanej strefie klimatycznej od wieków były użytkowane i przekształcane. To działalność człowieka nadała im wyjątkowy krajobraz. Łąka, tak jednoznacznie kojarzona obecnie z doliną, jest efektem działalności człowieka, a wprowadzenie jej do krajobrazu znacznie wzbogaciło różnorodność biologiczną i podniosło wartości estetyczne dolinn ${ }^{23}$. Obecnie określenie „,dolina naturalna" nie oznacza doliny nietkniętej przez człowieka, ale dolinę, której składniki przyrodnicze zostały częściowo zmienione użytkowaniem i pracą człowieka. Jest to dolina odziedziczona po tysiącu lat harmonijnego, niedegradującego użytkowania jej zasobów roślinnych i wodnych. Użytkowanie ograniczyło pierwotne składniki przyrody, ale ich nie zniszczyło, wprowadzając nowe wartości. Za naturalną uważamy dolinę, w której: rzeka płynie w miarę naturalnym łożysku (nieprostowana, niekanalizowana, niezabudowana), ma stosunkowo czyste wody, na równinie zalewowej są łąki lub pastwiska. Starorzecza nie są zasypane, brzegi rzeki mają naturalną roślinność, torfowiska dolinne nie zostały całkowicie osuszone, a wśród łąk są płaty lasu łęgowego. Obwałowania rzeki i mosty ujmują dolinie naturalności, ale jej tej naturalności nie pozbawiają ${ }^{24}$.

W przypadku analizowanego odcinka doliny Warty kilka wieków użytkowania ukształtowało harmonijny wiejski krajobraz kulturowy. Przekształcenia antropogeniczne były wprowadzane stopniowo i dostosowane do środowiska przyrodniczego. W obecnym krajobrazie doliny ważne są zarówno elementy przyrodnicze, jak i kulturowe. Pola uprawne i łąki są głównym elementem krajobrazu kulturowego doliny. Duży udział linii prostych miękkich i falistych związany jest z kształtem rozłogów i przebiegiem miedz. Dlatego szczególnie ważnym elementem krajobrazu wiejskiego są rozłogi, które łączą w sobie elementy natury i kultury. Informują o sposobach gospodarowania, a także o stanie środowiska przyrodniczego. Najcenniejszym urozmaiceniem krajobrazu rolniczego są zadrzewienia śródpolne oraz drzewa i krzewy (wierzby, topole) wzdłuż cieków, nawet tych ukształtowanych przez człowieka, tworzące powiązania koryta z otoczeniem. Najatrakcyjniejszy krajobraz dolinny został ukształtowany w obrębie terasy nadzalewowej niskiej w miejscu jej rozcięcia przez dawne koryta. Chociaż dolina rzeczna ma środowisko przyrodnicze bardziej zmienione niż wysoczyzna, to jednocześnie przechowuje więcej wartości naturalnych. Związane jest to z produktywnością siedlisk dolinnych i wielkością dynamiki ekosystemów dolinnych. Ta różnorodność, zdecydowanie większa niż na wysoczyźnie, jest w dużym stopniu osiągnięciem kulturowym.

\footnotetext{
${ }^{23}$ R. Olaczek, Antropogeniczne czynniki przekształcenia...

${ }^{24}$ Ibidem.
} 


\section{Bibliografia}

Armand D.L., Nauka o krajobrazie, PWN, Warszawa 1980.

Bogdanowski J., Problemy architektury krajobrazu rzecznego, [w:] J. Kułtuniak (red.), Rzeki. Kultura-cywilizacja - historia, t. 2, Śląsk, Katowice 1993, s. 61-75.

Borowska-Stefańska M., Zagospodarowanie terenów zagrożonych powodziami w Uniejowie, „Biuletyn Uniejowski” 2015, nr 4, s. 131-142.

Chmielewski T.J., Systemy krajobrazowe. Struktura - Funkcjonowanie - Planowanie, PWN, Warszawa 2012.

Czyż J., Forysiak J., Kamiński J., Klatkowa H., Szczegółowa Mapa Geologiczna Polski w skali 1:50 000, arkusz Dobra (587), PIG, Warszawa 2004.

Europejska Konwencja Krajobrazowa sporządzona we Florencji dnia 20 października 2000 r., Dz.U. Nr 14, poz. 98 z dnia 29 stycznia 2006 r.

Forysiak J., Rozwój doliny Warty między Burzeninem i Dobrowem po zlodowaceniu Warty, „Acta Geogr. Lodz.” 2005, Vol. 90.

Forysiak J., Kulesza M., Twardy J., Wpływ osadnictwa olęderskiego na sieć rzeczna i morfologię międzyrzecza Warty i Neru, [w:] E. Smolska, P. Szwarczewski (red.), Zapis działalności człowieka w środowisku przyrodniczym, t. III, Wydawnictwo Szkoły Wyższej Przymierza Rodzin, Warszawa 2007, s. 39-45.

Kamiński J., Forysiak J., Szczegółowa Mapa Geologiczna Polski w skali 1:50 000, arkusz Uniejów (588), PIG, Warszawa 2008.

Kistowski M., Bierna ochrona krajobrazu jako podstawa utrzymania korzystnych warunków życia człowieka, „Przegląd Przyrodniczy” 2010, t. XXI, z. 2, s. 18-30.

Kobojek E., Naturalne uwarunkowania równych reakcji rzek nizinnych na antropopresję na przykładzie środkowej Bzury i jej dopływów, Wydawnictwo Uniwersytetu Łódzkiego, Łódź 2009.

Kobojek E., Wplyw warunków klimatycznych na system fluwialny i melioracje wodne $w$ pradolinach w rejonie Łowicza i Koźmina (Polska Środkowa), „Przegląd Naukowy. Inżynieria i Kształtowanie Środowiska” 2015, vol. 24(4), nr 70, s. 381-390.

Kopczyński K., Edukacyjne walory krajobrazu kulturowego, „Problemy Ekologii Krajobrazu” 2009, t. XXV, s. 53-62.

Kozłowski L., Rozłogi wsi jako treść krajobrazu, „Studia Obszarów Wiejskich” 2012, t. XXIX, s. 9-30.

Kucharski L., Barcka A., Chmielecki B., Flora starorzeczy $w$ dolinie Warty - stan, zagrożenia oraz możliwości ochronnych, „Biuletyn Uniejowski” 2013, nr 2, s. 23-38.

Kurowski J.K., Ekologia i ochrona roślinności leśnej, EKO-GRAF Adam Świć, Łódź 2015.

Nowak-Rząsa M., 2010, Transformacja krajobrazów Polski - ocena kierunków i perspektywy rozwoju, [w:] D. Chylińska, J. Łach (red.), Studia krajobrazowe a ginace krajobrazy, Uniwersytet Wrocławski, Wrocław 2010, s. 21-28.

Myga-Piątek U., Przemiany krajobrazów kulturowych w świetle idei zrównoważonego rozwoju, „Problemy Ekorozwoju” 2010, vol. 5, nr 1, s. 95-108.

Olaczek R., Antropogeniczne czynniki przekształcenia dolin rzecznych, [w:] J. Kułtuniak (red.), Rzeki. Kultura-cywilizacja-historia, t. 9, Wydawnictwo Śląsk, Katowice 2000, s. 119-142.

Petera-Zganiacz J., Forysiak J., Historia rozwoju doliny Warty w basenie uniejowskim, „Biuletyn Uniejowski” 2012, nr 1, s. 23-41.

Richling A., Solon J., Ekologia krajobrazu, PWN, Warszawa 2002.

Tkocz J., Organizacja przestrzenna wsi w Polsce, Wydawnictwo Uniwersytetu Śląskiego, Katowice 1998.

Ustawa z dnia 23 lipca 2003 r. o ochronie zabytków i opiece nad zabytkami (Dz.U. Nr 162, poz. $1568 \mathrm{z}$ późn. zm.).

Wejchert K., Elementy kompozycji urbanistycznej, Wydawnictwo Arkady, Warszawa 1884.

[Wpłynęło: kwiecień 2016; akceptacja: maj 2016] 


\title{
CULTURAL LANDSCAPE OF THE WARTA VALLEY NEAR UNIEJÓW
}

\begin{abstract}
Summary
Cultural landscape is a historically formed part of geographical space which emerged as a result of natural and cultural impacts. It reflects the co-existence of people and nature. The paper presents the cultural landscape of a part of the Warta valley near Uniejów and undertakes its evaluation. The analysis took into account the land use forms and the degree of anthropogenic transformation of the landscape.

Several centuries of human habitation have created a harmonious rural culture landscape in the Warta valley in the Uniejów region. The land use structure shows adjustment to the natural elements of the valley. Arable land and forests take up the largest area $-37.5 \%$ and $36.2 \%$ respectively; meadows, which are so typical of river valleys, constitute $21 \%$, and built up land - only $1.8 \%$ of the area. The most attractive landscape has formed above the flood plain, with mosaic-shaped land use forms, long baulks, groups of trees among the fields and rows of trees along water flows.
\end{abstract}

Keywords: cultural landscape, rural commune, Warta river valley, Uniejów 